\title{
Beyond Balancing? Intrastate Conflict and US Grand
} Strategy

\author{
Doug Stokes \& Kit Waterman.
}

\section{Department of Politics}

University of Exeter, UK.

\begin{abstract}
Grand strategic theorists share an historical emphasis on interstate conflict. However, of some two hundred and seventy-three US military deployments since 1900, only seven were interstate conflicts. The rest were intrastate, domestic level engagements. We argue that these intrastate conflicts limit the utility of regional balances of power in mitigating forms of conflict that the US may consider inimical to its national security interests. When considering potential changes to US force posture and grand strategy, American coercive statecraft should be theorised along a broader strategic continuum encompassing the full range of conflict.
\end{abstract}


Whilst debates on US grand strategy tend to disagree over the options and risks associated with either retrenchment or deep engagement, they share an emphasis on interstate warfare in their respective analyses. This interstate focus informs the often diametrically opposed calls for changes in US force posture and grand strategy and is justifiable given the fact that historically it has been both the most destructive and transformative of international relations. Attendant US grand strategies thus place interstate conflict at the core of US national security interests. ${ }^{1}$ However, as Brooks and Wolhforth note, 'grand strategy's implications for nonstate and transnational policy challenges like terrorism tend to be indirect - though crucial'. ${ }^{2}$ We agree with this. Aside from the capacity for intrastate wars to pull the US into larger interstate conflicts or to trigger forms of regional instability, in terms of historical regularity these smaller forms of conflict have often been the principal focus of US overseas military missions. Since 1900 only seven of the two hundred and seventy-three US military deployments were in fact interstate conflicts, with the remaining being smaller scale strikes and intrastate interventions. ${ }^{3}$ In short, a significant proportion of US coercive statecraft has for over a century been directed towards unconventional and asymmetric intrastate interventions. Whilst there is a plethora of strategic scholarship on small wars, terrorism, insurgency and so on, these pervasive forms of conflict have often only found their way into the grand strategy scholarship in fleeting and tangential ways. ${ }^{4}$ This is both an interesting empirical and theoretical lacunae. Does the inclusion of these smaller scale intrastate conflicts change America's grand strategic calculus? This paper seeks to explore this issue and we develop two key arguments.

\footnotetext{
${ }^{1}$ Barry Posen is one of the few retrenchers that briefly mentions intrastate conflict but even here it is only with respect to large, boots-on-the-ground interventions. See his Restraint: A New Foundation for U.S. Grand Strategy (Ithaca: Cornell University Press, 2014) pp, 51-60. On major wars and their ending see G. John Ikenberry, After Victory: Institutions, Strategic Restraint, And The Rebuilding of Order After Major Wars (New Jersey: Princeton University Press, 2000).

${ }^{2}$ Stephen Brooks \& William Wohlforth, America Abroad. The United States' Global Role In The 21st Century (Oxford: Oxford University Press, 2016), p.81

${ }^{3}$ Barbara Salazar Terreon, "Instances of Use of United States Armed Forces Abroad, 1978-2015" Congressional Research Service, October 15, 2015. http://fas.org/sgp/crs/natsec/R42738.pdf; author's own research.

${ }^{4}$ On US interventions and intrastate warfare during the Cold War see Michael McClintock, Instruments of Statecraft: US Guerrilla Warfare, Counterinsurgency, and Counter-terrorism, 1940-1990 (New York: Pantheon Books, 1992). See also Edward Newman, Understanding Civil Wars: Continuity and change in intrastate conflict (London: Routledge, 2014).
} 
First, we examine US coercive statecraft and argue that the US's post-war project of liberal international order building had both a militarised but also a political economic component. 'Deep engagers' often posit the merit of defense commitments in achieving economic outcomes, suggesting that 'the United States gets better economic bargains or increased economic cooperation on some specific issues than it would if it did not play such a key security role, whilst 'retrenchers' argue that deep engagement advocates 'ignore the extent to which past U.S. military activism has actually undermined market stability and upset vital regions. ${ }^{6}$ Both have merit, but neither systematizes intrastate arguments into their broader grand strategic logics which, we argue is a significant omission as it is often these forms of intrastate security regimes that gives the US significant leverage in shaping the economic preferences of recipient states. In short, these sub-state intrastate forms of security assistance have also formed a key means through which the US has helped structure specific forms of political and economic governance that it has considered conducive to its broader global leadership role. As noted, both 'schools' recognise this but do not drill down to explore this at the intrastate level and the potential implications this has for the wider grand strategic debates.

Second, the shared focus on interstate conflict cannot on its own theoretical terms address the ways in which either retrenchment or a re-calibrated variant of deep engagement would deal with or influence forms of internal instability that may emerge from changes in American force posture. For example, how would US offshore balancing deal with domestic instability or sub-state actors, or US supported 'onshore' proxies deter forms of intrastate instability? Minimally, given the pervasive, historically intense and ongoing nature of intrastate conflict, ${ }^{7}$ grand strategy debates should widen the optic through which US coercive statecraft is understood. Rather than a strict interstate / intrastate binary, we argue it is helpful to conceptualize conflict across a broader strategic continuum that encompasses both of these

\footnotetext{
${ }^{5}$ Brooks et al. "Don't Come Home," 42

${ }^{6}$ Christopher Preble and William Ruger, "No More of the Same: The Problem with Primacy" War on the Rocks August 31, 2016. http://warontherocks.com/2016/08/no-more-of-the-same-the-problem-with-primacy/

${ }^{7}$ The Uppsala Conflict Data Program estimates that approximately one million battle deaths may be attributable to intrastate conflict since 1989. See, “UCDP Battle-Related Deaths Dataset” UCDP, Uppsala University, Department of Peace and Conflict Research. http://www.pcr.uu.se/research/ucdp/datasets/ucdp_battle-related deaths dataset/
} 
dimensions. This does not mean we attribute equal weight to each form of conflict and by extension the balance of calculations that the US may need to make either regionally or globally. However, the current scholarship on US grand strategy significantly underweights intrastate conflict, and that presents an interesting theoretical challenge given the scholarship's emphasis on interstate balances of power acting to mitigate threats to US national security interests; are intrastate conflicts beyond interstate balancing?

We proceed as follows. First we cover the theoretical debates and assumptions underpinning the analysis of grand strategy. Second, we present our database of US military operations, and drawing on official budgetary data and private and official arms sales reports, present a breakdown of the resources expended on military aid and training from 1990 onwards. Where data granularity permits, we also specify a more detailed analysis of aggregate security assistance and arms sales data throughout the 2000s in the Middle East, Latin America and Africa. In the third and final section we then propose a theoretical resolution that seeks to reconcile these theoretical debates to the empirical material.

\section{Interstate Conflict and Grand Strategy}

Within grand strategic debates, great power relationships tend to be the central objects of analysis. Whilst justifiable given the capacity of major interstate war to change global balances of power or impact on core US national security interests, it has often meant the occlusion of substate level conflict in the discussion and analysis of grand strategy. Historically, the US has been engaged in a large number of smaller scale security assistance and training programs. As the 2008 US Stability Operations manual underscores:

'During the relatively short history of the United States, military forces have fought only eleven wars considered conventional. From the American Revolution through Operation Iraqi Freedom, these wars represented significant or perceived threats to national security interests, where the political risk to the nation was always gravest. These were the wars 
for which the military traditionally prepared; these were the wars that endangered America's very way of life. Of the hundreds of other military operations conducted in those intervening years, most are now considered stability operations, where the majority of effort consisted of stability tasks. Contrary to popular belief, the military history of the United States is one characterized by stability operations, interrupted by distinct episodes of major combat. ${ }^{8}$

Thus, while strategic discourse focuses on the threat of major war, many of the day-to-day applications of American military power concern more routine and smaller scale operations to stabilise other nations in order to defend and expand the US-led liberal international order that has both an political and economic component. ${ }^{9}$

Recent scholarship outlines two broad conceptual pathways that link US security and economic interests; what is termed micro and macro level structuring. Micro-level structuring describes the added advantage the United States derives from its security role in negotiating economic agreements, reflecting the Cold War logic of foreign policy 'linkage'. Described by Henry Kissinger as method of combining a 'network of incentives and penalties to produce the most favourable outcome. ${ }^{10}$ On the other hand, macro-level structuring refers to the manner in which military commitments coalescence around a US-centric status quo thereby institutionally instantiating sets of American preferences. In short, 'what the United States wants from the economic order is simply "more of the same" and the best way to achieve that is to raise the costs of revising the system whilst keeping the benefits of a pacified security system coming. ${ }^{11}$ However, the historical record suggests a far more hands on element to this economic logic. That is, whilst we agree with the arguments made in favour of micro and macro-level structuring at the interstate level, there are important intrastate dynamics as well, most of which are missing

\footnotetext{
${ }^{8}$ US Army, Stability Operations, FM 3-07, October 2008, http://usacac.army.mil/cac2/Repository/FM307/FM3-07.pdf , p.1-1.

${ }^{9}$ Christopher Layne, The Peace of Illusions: American Grand Strategy from 1940 to the Present (Ithaca: Cornell University Press, 2006); Bastiaan Van Apeldoorn and Nana de Graaff, American Grand Strategy and Corporate Elite Networks: The Open Door since the End of the Cold War (Oxford: Routledge, 2015)

${ }^{10}$ Henry Kissinger, Diplomacy (London: Simon \& Schuster, 1994), p.717

11 Brooks et al. "Don't Come Home, America", 42-44
} 
from much of the theoretical literature on US grand strategy and problematic not least (as we develop below) as they miss the ways in which these sub-state security regimes have allowed the US to configure a specific form of international order.

For instance, Posen's recent work, Restraint, arguably one of the most in depth arguments for American retrenchment, hardly covers the wider economic implications of grand strategic adjustment. In keeping with many scholars writing in favour of retrenching from American deep engagement, the economic aspects of US grand strategy only examines the 'blood and treasure' costs associated with military adventurism. That is, the casualty rates of the conflicts in Iraq and Afghanistan as well as on the how much more, proportionally, the United States spends on defence relative to its alliance partners. By doing so, Posen also conflates contemporary military adventurism with the broader strategy of deep engagement, attempting to draw a connection between recent strategic failures and grand strategic doctrine. ${ }^{12}$ However, this is problematic. After all, a grand strategy does not tell us much about specific policy decisions themselves, but rather aims to inform the manner in which planning and deployment are approached more generally. Strategic doctrine is a set of concepts and principles that guides the allocation of national resources to achieve national interests. Consequently, by definition, it 'cannot tell us about the optimality of decisions outside the strategy's core logic'. ${ }^{13}$

However, Posen's omission of economic and intrastate factors is far from unique. Most of the key works on grand strategy in the last decade or so have primarily focused on force posture considerations $^{14}$ described as '... the term for how U.S. military forces are arrayed around the world. This includes numbers and types of major combat units...and the array of bases that house or support them. ${ }^{15}$ As we noted earlier, it was Wohlforth et al who have described some of the

\footnotetext{
12 Barry Posen, Restraint: A New Foundation for U.S. Grand Strategy (Ithaca: Cornell University Press, 2014) Chapter 1

${ }^{13}$ Campbell Craig et al. "Debating American Engagement: The Future of U.S. Grand Strategy" International Security 38:2 (2013) p, 199

${ }^{14}$ For example, Stephen Walt, Taming American Power: The Global Response to U.S. Primacy (New York: W.W. Norton \& Company, 2005); Christopher Layne, The Peace of Illusions: American Grand Strategy from 1940 to the Present (Ithaca: Cornell University Press, 2006).

${ }^{15}$ Posen, Restraint, 158
} 
key mechanisms linking economic and security aspects of American grand strategy. Despite this, they occlude mention of intrastate dynamics. The rationale, in their own words, is that

'In any given period, the United States does many things other than those related to the basic grand strategy, and many foreign policy debates are about those issues rather than directly about the core. ${ }^{16}$

However, as we hope to demonstrate, intrastate order making has been a vital component of American statecraft throughout the last century. Whether the outcomes have been perceived to have been helpful or a hinderance, they have nonetheless had important implications for US national security.

\section{US Intrastate order making}

In the post-war period, the US steadily cultivated very close ties with numerous militaries around the world, justified as a necessary step in the fight against global communism. Pro-US states, protected by strong security forces, were thus incorporated into the US-led order as allies and strategic buttresses. Importantly, this form of order management principally relied upon the defense of recipient states and elites through forms of internal defense re-orientation for managing forms of internal order. These intrastate regimes became a central component of US power, and the commitments took on a range of levels of engagement. If we take just one example of the military training programmes run by the US, the International Military Education and Training (IMET) programme, over 700,000 foreign officers have passed through its programmes since 1950 at a cost of over $\$ 3$ billion. The programme continues to train thousands today. ${ }^{17}$

Throughout the Cold War, the justification for these close military to military contacts was frequently one of anti-communism linked to the bipolar competition with the USSR. As such,

\footnotetext{
${ }^{16}$ Brooks \& Wohlforth, America Abroad, 81

${ }^{17}$ U.S. Department of State, "International Military Education and Training Account Summary" 2016. http://www.state.gov/t/pm/ppa/sat/c14562.htm
} 
domestic instability became the key threat to US interests over and above interstate wars, which, given mutually assured destruction and strategic tripwires were far less frequent than the many covert proxy wars and US and Soviet backed insurgency and counterinsurgency campaigns. Given the often fragile social bases of a number of pro-US states during the Cold War, coupled with rapid decolonization in the post-war period, it is perhaps unsurprising that the vast majority of US military operations were dedicated to domestic security assistance.

Although the rationales changed in the post-Cold War period, this form of intrastate order mediation has not changed significantly. The 2008 Stability Operations manual notes, the "greatest threats to our national security will not come from emerging ambitious states but from nations unable or unwilling to meet the basic needs and aspirations of their people" with US operations designed to 'rebuild the institutions of government and market economy that provide the foundations for enduring peace and stability' which is the 'essence of stability operations'. Today, the US continues to commit billions of dollars in aid and training to a variety of militaries around the world. ${ }^{19}$ 'We will strengthen U.S. and international capacity to prevent conflict among and within states' argues the 2015 National Security Strategy with, 'the nexus of weak governance and widespread grievance allow[ing] extremism to take root, violent non-state actors to rise up, and conflict to overtake state structures'.

As table one details, the types of military operations the United States has undertaken since the end of the Cold War are overwhelmingly intrastate interventions. In the formulation we define Operation Desert Storm, Operation Iraqi Freedom, and the opening stages of Operation Enduring Freedom (Afghanistan) as interstate conflicts. Outside of this arguably generous definition, what is notable is the sheer scale of military operations undertaken by US forces over the last twenty five years. Moreover, the operations we list below exclude most, if not all, special operations

\footnotetext{
18 US Army, Stability Operations, FM 3-07, October http://usacac.army.mil/cac2/Repository/FM307/FM3-07.pdf, p.V.I.

19 For data of arms and training see the US Department of State, Foreign Assistance Budget Releases website http://www.state.gov/f/releases/iab/index.htm

${ }^{20}$ The White House, "National Security Strategy" February 2015. p, 10

https://www.whitehouse.gov/sites/default/files/docs/2015 national security strategy.pdf
} 
deployments, likely resulting in a far smaller set of observations than is actually the case. The categorization in use is idiosyncratic, designed to disaggregate the types of missions into a number of different forms of conflict that allow for a more informative, illustrative appraisal of operational types rather than simply demarcating between interstate and intrastate conflict alone.

One of the more obvious features of US post-Cold War operations has been the pervasiveness of humanitarian operations, accounting for twenty eight percent of overall deployments recorded. However, in terms of more security focused missions, we can also see that the US military has conducted a wide range of operational types in the post-Cold War era, ranging from supporting allied nations, to conducting deterrence operations. In itself, the wide range of these operations attest to the fungibility of military force across a number of issue areas with approximately thirty six percent of the operations recorded involving supporting or training allies to better control contested or unstable territory. Moreover, as mentioned previously, this figures excludes most Special Forces deployments which, given that fact that US special operations forces deployed to 135 countries in 2015 alone, is likely to significantly understate American intrastate interventions. $^{21}$

\footnotetext{
${ }^{21}$ Doug Bolton, "American special operations forces have been deployed to 135 countries this year alone" The Independent, September 24th, 2015 ; Nick Turse, "U.S. Special Ops Forces Deployed in 135 Nations" Tom Dispatch, September 24, 2015.
} 
Table 1. Post-Cold War Operations, by Type

\begin{tabular}{|c|c|c|}
\hline Type & Example & Count \\
\hline Interstate & Eg. Operation Desert Storm & 3 \\
\hline Humanitarian & Eg. Operation Damayan & 27 \\
\hline Counterinsurgency/ Counterterrorism & Eg. Operation Enduring Freedom & 9 \\
\hline Training & $\begin{array}{l}\text { Numerous training missions - Iraq/Syria/Central } \\
\text { Africa }\end{array}$ & 7 \\
\hline Security Operations & $\begin{array}{c}\text { Deployments to protect American citizens and } \\
\text { property }\end{array}$ & 13 \\
\hline Evacuation/Hostage Rescue & Eg. Operation Eastern Exit & 16 \\
\hline Deter/Enforce/Strike & Eg. Operation Desert Fox & 14 \\
\hline Allied Support & Eg. US support for Operation Serval & 5 \\
\hline
\end{tabular}

Source: Barbara Salazar Terreon, "Instances of Use of United States Armed Forces Abroad, 1978-2015" Congressional Research Service, October 15, 2015; Author's own calculations (see footnote 4 for details)

Note: The categorization is not definite, rather illustrative. However, the broad groupings are unlikely to be subject to considerable change irrespective of specific disagreements over operational type. The database for post-Cold War operations contains one hundred and sixty-two observations, although only ninety-four are categorized bere. Those omitted are mostly repeat observations already listed or follow up operations directly related to a previous operation. Including these observations may have contributed to inflate the number of operations undertaken through double-counting.

In a more general sense, the operations that the American military often undertake seek to address "capacity deficits" which are taken as indicative of failing state infrastructure that reinforce the propensity for instability. These domestic deficits include, amongst others, "systemic economic stagnation" and "scarcity of necessary resources",22 with proposed solutions including the implementation of the "rule of law, developing human capital, providing social welfare, providing security, managing the use of force, and establishing commercial markets."23 Former Defense Secretary, Robert Gates, reaffirmed that the principal strategic element in the War on Terror (WoT) "is not the fighting we do ourselves, but how well we enable and empower

${ }^{22}$ Department of the Army, "Field Manual No. 3-07 Stability" June 2, 2014. pp, 4-6 http://armypubs.army.mil/doctrine/DR_pubs/dr_a/pdf/fm3 07.pdf

${ }^{23}$ Department of the Army, "Field Manual No. 3-07 Stability", pp,3-2 
others to defend and govern their own countries. The standing up and mentoring of indigenous armies and police - once the province of Special Forces - is now a key mission for the military as a whole." 24

Linked to this, the United States also expends considerable resources funding security assistance programmes for a large number of nations, as well as subsidizing and facilitating the sale of large quantities of arms and equipment. In figure 1 we display time series of such military aid combined with US arms sales beginning in 2000. We include both foreign military sales (FMS) and direct commercial sales (DCS). The main difference between the two is that the latter are organised privately between US companies and foreign buyers, whereas the former is run through the Department of Defense and has linkages with the foreign military financing (FMF) where applicable. As we can see, all indicators demonstrate that there has been an increase in the amount of military aid and arms sales delivered to the rest of the world over this time period. Whereby the rather obvious spike occurring in 2013 is largely attributable to the Japanese having placed an unusually large order of arms from the United States in that year. ${ }^{25}$

24 Robert Gates, 'Remarks delivered at the Association of the United States Army', 10 October 2007. http://www.defenselink.mil/speeches/speech.aspx?speechid=1181.

${ }^{25}$ U.S. Department of State, Directorate of Defense Trade Controls. "2013 Section 655 Report” Section 655 Annual Military Assistance Reports.

https://www.pmddtc.state.gov/reports/documents/rpt655 FY13.pdf 
Figure 1 - Arms Sales and Security Assistance, 2000-2015

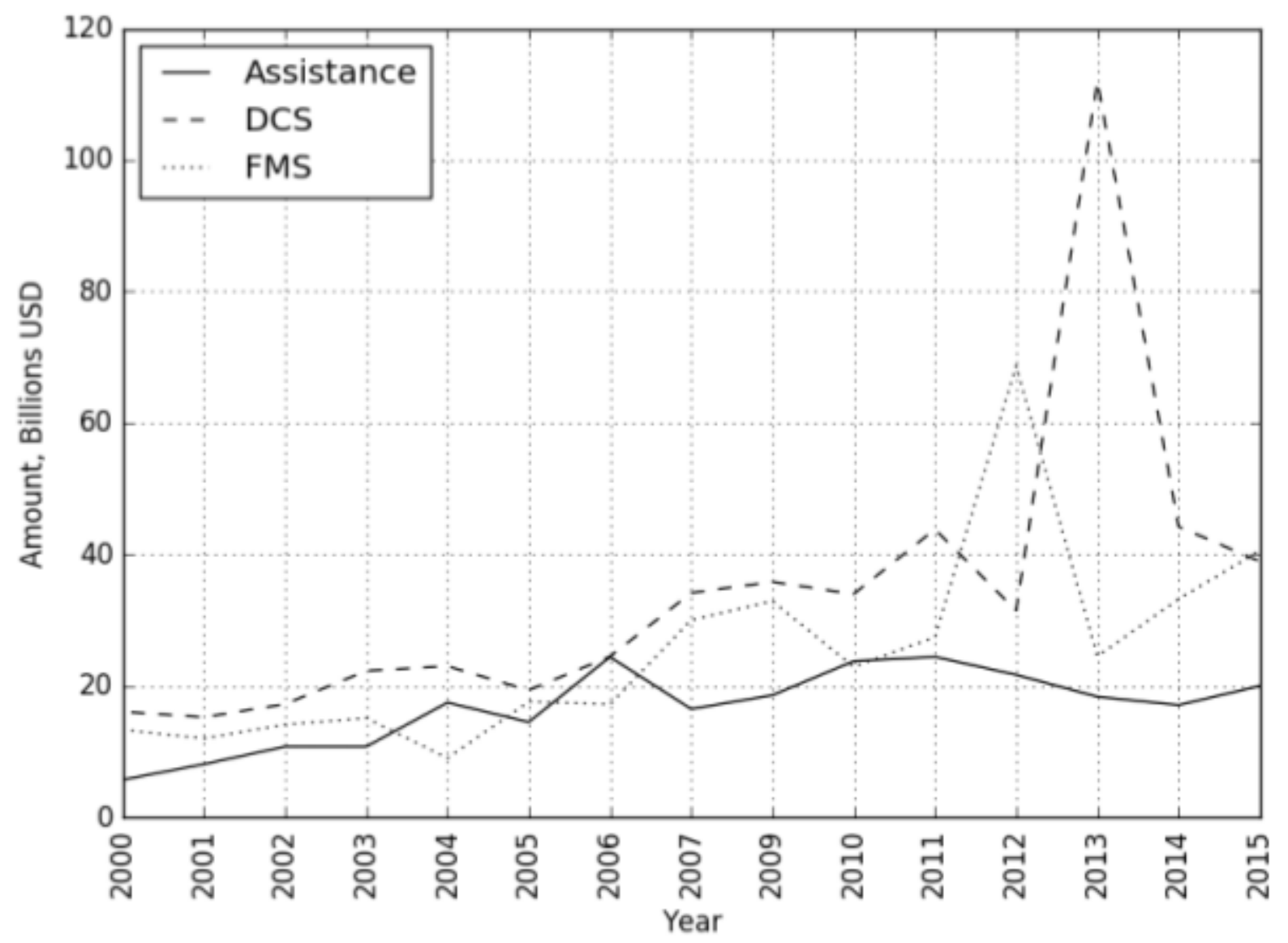

Sources: Security Assistance Monitor, 2017. http://securityassistance.org/data : Department of Defense, "Foreign Military Sales, Foreign Military Construction Sales and Other Security Cooperation Historical Facts", Security Cooperation Agency. September 2015. hitt:/humw.dsca.mil/sites/defaultfililes/fiscal_year_series_-30_september_2015.pdf

As is apparent, our empirical data is quite clear: American involvement in intrastate warfare and domestic security regimes has been ubiquitous with both 'retrenchment' and 'deep engagement' scholarship often examining these forms of overseas missions in tangential ways (if at all).

This omission in the grand strategic literature becomes theoretically more interesting when we consider the fact that interstate balances of power are often posited as the means by which US force posture can be recalibrated without having to worry too much about about possible post-American regional security orders developing in ways that may be inimical to US national 
security interests. When we factor this intrastate element to grand strategic calculations, how can interstate balances of power prevent possible negative intrastate conflict dynamics from developing? This is arguably most problematic for 'offshore balancers' whose reliance on post-retrenchment pro-US 'onshore balancers' operates almost entirely at the interstate level. In essence then, new post-American regional balances of power, the mechanism that operationalises its capacity to choose retrenchment, operates entirely at the interstate level with at present little analysis of intrastate dynamics. Our call is not to necessarily give equal weighting to this interstate / intrastate dyad in American strategic calculations, but we have hoped to demonstrate that minimally, this sub-state dimension should find its way into grand strategic debates when weighing US options, not least because of its prevelance. As we covered earlier, 'deep engagement' advocates do tend to more directly integrate political-economic arguments into their analyses, but there is a tendency to omit evaluation of internal order making in favour of those mechanisms that address grander interstate developments. ${ }^{26}$ In terms of impact, and particularly resources, while there is a sound justification for the primacy accorded to interstate dynamics, this does not equate to largely ignoring intrastate developments. In this sense, the lack of engagement can only contribute to underspecify our understanding of the role of American power in generating desired international outcomes; particularly, as we have identified above, intrastate dynamics have played such a pervasive role in American statecraft.

In the following section we empirically underscore this by examining the contributions that security assistance and stability operations have made to achieving US economic and strategic objectives. We focus the analysis on the funds and resources allocated to Latin America, the Middle East, and Africa. The remaining regions, particularly the broader Asia-Pacific and Europe, are omitted. Not only is Europe a central partner in the American led, liberal international economic order. But because of its wealth, general stability, and its close resemblance to the form of political economy deemed most amenable to US interests, it receives very little in the way of domestic security support. Likewise, in relation to support for intrastate order building, American interaction with the broader Asia-Pacific has also been rather limited,

\footnotetext{
${ }^{26}$ Stephen Brooks et al. "Don't Come Home, America: The Case Against Retrenchment" International Security 37:3 (2012/13) pp. 42-45
} 
with the only major exception being Japan. A nation whose recent history and economic characteristics have been shaped in much the same way as those of Europe. Broader engagement with the region has been limited by a number of historical contingencies, not least a mixture of failed interventions and hostile political ideologies. Because of this, our sample can be reduced to the remaining three regions of the globe.

\section{Latin America}

In Latin America, US intrastate security regimes have been explicitly linked to defending US national interests beyond strategic threats to also include a broader political economy and stabilisation component. For example, in confirmation hearings for the job of Commander of USSOUTHCOM in 2000, just as Colombian drug violence was peaking, ${ }^{27}$ General Peter Pace was clear that the vital national interests of the US, which he defined as "those of broad, overriding importance to the survival, safety and vitality of our nation," included, "continued unhindered access to strategic natural resources in the USSOUTHCOM AOR [area of responsibility]", alongside a "continued stability required for access to markets in the USSOUTHCOM AOR, which is critical to the continued economic expansion and prosperity of the United States." Indeed, Pace went on to explain that "our trade within the Americas represents approximately 46 percent of all US exports, and we expect this percentage to increase in the future." 28 More recently, the posture statement of former SOUTHCOM Commander, General Douglas M. Fraser, further reaffirmed the centrality of Latin America and the Western Hemisphere to US economic and political interests. He argued that the "Western Hemisphere is the United States' largest market with nearly 38 percent of US trade travelling north and south, equating to \$1.5 trillion." Moreover, in resource terms, the US obtains "more crude oil imports - 52 percent-from this region than from the Persian Gulf, which only provides 13 percent." He continued that the

\footnotetext{
${ }^{27}$ Centro Nacional de Memoria Histórica, “iBasta Ya! Colombia: Memorias De Guerra Y Dignidad”, July 2013. p, 32

http://www.centrodememoriahistorica.gov.co/descargas/informes2013/bastaYa/bastaya-colombia-memorias-de-guer ra-y-dignidad-2015.pdf

${ }_{28}$ Peter Pace, Advance Questions for Lieutenant General Peter Pace. Defense Reforms. United States Senate Committee on Armed Services. 2000. http://www.senate.gov/ armed_services/statemnt/2000/000906pp.pdf.
} 
"Commerce Department reports the overall sum of US foreign direct investment in the hemisphere (minus Canada) is 17.8 percent of our total foreign direct investment worldwide. Further, ten of the 17 US Free Trade Agreements are with countries in the Americas. In terms of percentage, our total foreign direct investment in the hemisphere (including Canada) equals our direct investment in Asia, the Middle East and Africa, combined." 29

Because of this, Latin American states have often been the recipient of billions of dollars of US defense aid and training in the post-Cold War period, nearly all of which has focussed on stability operations. These stability operations tend to be a part of broader packages of reforms that seek to open up these states' economies, helping to advance American economic interests. For example, the US signed the Central America Free Trade Agreement (CAFTA) with Costa Rica, the Dominican Republic, El Salvador, Guatemala, Honduras and Nicaragua in $2004^{30}$ Itself predicated on the long period of financial and economic liberalisation that had been linked to counterinsurgency operations and security funding throughout the eighties and nineties. As the agreement came into force, tariffs on the majority of goods were eliminated, and trade has since expanded, with the majority of trade in the US's favor. Indeed, the deal eliminated more than 80 percent of existing duties on US manufacturing exports to the region, as well as 50 percent of US agricultural exports. As a consequence, US exports to participating states expanded by 16 percent in the first full year of the agreement's operation (2006) when compared to the previous year, with parallel imports from the region rising just 3 percent; overall figures which hide larger discrepancies in particular cases. As of 2014, the United States is Mercosur's - Latin America's largest trading block - second largest trade partner, with only the European Union achieving greater aggregate trade flows. ${ }^{31}$

\footnotetext{
${ }^{29}$ General Douglas M. Fraser, Posture Statement of General Douglas M. Fraser before the United States Southern Command, Senate Armed Services Committee. March 11, 2010. http://armed-services.senate.gov/statemnt/2010/03percent20March/Fraserpercent2003-11-10.pdf

${ }^{30}$ Also known as the Dominican Republic-Central America Free Trade Agreement (DR-CAFTA). See: 'Central American Trade Deal Done', BBC News, 28 May 2004. http://news.bbc.co.uk/1/hi/business/3759371.stm

${ }^{31}$ European Commission, "Trade, Countries and regions - Mercosur" August, 2014.

http://ec.europa.eu/trade/policy/countries-and-regions/regions/mercosur/
} 
Of the wide range of American security assistance programs, most aid has been disbursed through INCLE (International Narcotics Control and Law Enforcement), the counternarcotics program through which funding has been channelled to Colombia and Mexico as part of 'Plan Colombia' and the 'Merida initiative' respectively. The United States considers that transnational organised crime (TOC) "threatens U.S. economic interests and can cause significant damage to the world financial system through its subversion, exploitation, and distortion of legitimate markets and economic activity." ${ }^{32}$ Recognition of this fact, in addition to the concerns over drug trafficking more generally, have been the key driving forces in the United States anti-Narcotics security assistance. Indeed, both previously stated initiatives were aimed at 'armouring' the Colombian and Mexican states to facilitate their capacity to disrupt drug trafficking organisations operating within their territory. This objective is quickly verified when one considers the funding composition of these programs.

For instance, under the Merida Initiative announced in late 2007, the United States has allocated over $\$ 2.5$ billion dollars in funding to Mexico as of 2017 . Yet over $90 \%$ of this funding was directed to security assistance and arms transfers, particularly the equipment and training programs provided by the INCLE framework. This left only $\$ 235$ million allocated to Economic Support Funds (ESF) over the period FY2007 to FY2016. ${ }^{33}$ The primacy accorded to securing investments can be seen in reports detailing the progress of these programs, with concern that violence in Mexico "threaten[s] citizen security and governance" immediately followed by the observation Mexico is a "country with which the United States shares a nearly 2,000-mile border and more than $\$ 500$ billion in annual trade." ${ }^{34}$ This isn't all that surprising. Mexico is America's third largest trading partner, integrated tightly into American manufacturing production chains,

\footnotetext{
${ }^{32}$ The White House, "Strategy to Combat Transnational Organized Crime: Addressing Converging Threats to National Security" July 2011. p,5

https://www.whitehouse.gov/sites/default/files/Strategy to_Combat_Transnational_Organized_Crime_July_2011.pd $\underline{f}$

${ }^{33}$ Clare Seelke and Kristin Finklea, "U.S.-Mexican Security Cooperation: The Merida Initiative and Beyond" Congressional Research Service, January 18, 2017. https://fas.org/sgp/crs/row/R41349.pdf

${ }^{34}$ Clare Ribando Seelje and Kristin Finklea, "U.S.-Mexican Security Cooperation: The Merida Initiative and Beyond" Congressional Research Service, May 7, 2015.
} 
with its economic and political stability long considered vitally important to the security and prosperity of the United States.

Likewise, the U.S.-Colombia Free Trade Agreement, which entered into force on May 2012, was the result, in part, of the declining rates of violence and better governance that Plan Colombia was intended to achieve. Indeed, while the FTA was proposed in 2006 it didn't go into effect until violence and labour rights concerns were suitably addressed, even supplying additional funds for programs especially designed to entrench gains in made in lessening anti-union violence. $^{36}$ Even the American Federation of Labor and Congress of Industrial Organizations (AFL-CIO) begrudgingly recognised that "the government of Colombia has made great efforts to reduce the power of armed organizations, modernize the economy and attract foreign investment." ${ }^{37}$ Assassinations of labor union activists and teachers decreased by $86 \%$ between the years 2002 and 2009, coinciding with broader declines in society wide violence more generally. $^{38}$

\section{The Middle East and South Asia}

With the War on Terror there has been a considerable shifting of military assistance to the Middle East. Whilst the majority of this expenditure is directed toward Israel and Egypt - a consequence of the Camp David accords - with $\$ 4.56$ billion of the likely $\$ 5.7$ billion FMF allocation for FY2017 earmarked for these two nations, ${ }^{39}$ there has been a large expansion in assistance to other regional actors. In particular, until recently, both the DoD and State provided

\footnotetext{
${ }^{35} \mathrm{On}$ this see, Angeles Villarreal, "U.S.-Mexico Economic Relations: Trends, Issues, and Implications" Congressional Research Service, April 20, 2015

${ }^{36}$ United States Trade Representative, "Colombian Action Plan Related to Labour Rights", April 7, 2011. https://ustr.gov/sites/default/files/uploads/agreements/morocco/pdfs/Colombian\%20Action\%20Plan\%20Related\%20 to\%20Labor\%20Rights.pdf

${ }^{37}$ American Federation of Labor and Congress of Industrial Organizations, "The Colombian Action Plan Related to Labor Rights: The View Through Workers' Eyes” July 2012. p,1

http://www.aflcio.org/content/download/38251/594971/report+version+2+no+bug.pdf

${ }_{38}$ M. Angeles Villarreal, "The U.S.-Colombia Free Trade Agreement: Background and Issues" Congressional Research Service, February 14, 2014. p,18 https://www.fas.org/sgp/crs/row/RL34470.pdf

${ }^{39}$ US Department of State, "Congressional Budget Justification: Department of State, Foreign Operations, and Related Programs - FY2017 Budget and Appropriations" October 5, 2016. P, 6 https://fas.org/sgp/crs/row/R44391.pdf
} 
significant military financing packages to Pakistan. Indeed, a Congressional Research Service document, dated 2013, details the fact that since 1948 "the United States has pledged more than $\$ 30$ billion in direct aid, about half for military assistance, and more than two-thirds appropriated in the post-2011 period. ${ }^{40}$ From 2009 through until 2013 the DoD and State jointly contributed $\$ 2.3$ billion dollars under the Pakistan Counterinsurgency Fund/Pakistan Counterinsurgency Capability Fund (PCF/PCCF), ${ }^{41}$ not to mention billions more in Coalition Support Funds (CSF). This funding is widely accepted to have been used to secure NATO access corridors to Afghanistan, as well as attempt to provide for some degree of state stability. ${ }^{42}$ Commitment to the professed rationales for many of these funds is quickly belied by the fact that many of these funds are delivered with very little oversight, and even where they have been, Pakistan has taken little heed of American preferences and requests. ${ }^{43}$ Outside of this rather cruder objective, as a recent report on the matter notes, there is unlikely to be much 'value-added' in supplying Pakistan with funds:

"It is true that the presence of Pakistani military forces in the FATA [Federally Administered Tribal Areas] curtails freedom of movement for al Qaeda and the Haqqani network, but there is little evidence to suggest that Pakistan would recall these forces if CSF stopped or U.S. security assistance was more narrowly focused on equipment only useful for counterrorism (as opposed to dual-use weapons systems). ${ }^{44}$

In reality these funds seem to have been rather limited, albeit potentially effective, payoffs to make an often irksome partner more amenable to US interests.

\footnotetext{
${ }^{40}$ Susan Epstein and Alan Kronstadt, "Pakistan: U.S. Foreign Assistance" Congressional Research Service, July 1, 2013.

41 "Direct Overt U.S. Aid Appropriations for and Military Reimbursements to Pakistan, FY2002-FY2016" Congressional Research Service, February 10, 2015

42 Dafna Rand and Stephen Tankel, "Security Cooperation and Assistance: Rethinking the Return on Investment" Center for a New American Security, August 2015. p, 10

${ }^{43}$ Susan Epstein and Alan Kronstadt, "Pakistan: U.S. Foreign Assistance" Congressional Research Service, July 1, 2013.

${ }^{44}$ Rand and Tankel, "Security Cooperation and Assistance", 18
} 
Likewise, funding streams to Saudi Arabia and Iraq continue to constitute the primary way in which the United States has managed its relationships with these nations, particularly, as in Iraq's case, after the withdrawal of American combat units. Alongside the presence of U.S. troops, Iraqi security aid, which has amounted to over $\$ 27$ billion since $2003,{ }^{45}$ has been a key modality for U.S. statecraft. While the (in)effectiveness of these military training programs has been brought into question by the Islamic State (IS) insurgency, debate as to whether this presence helped to cement the liberalization and production of Iraqi oil is less controversial. ${ }^{46}$ Not only have many of Iraq's largest oil fields attracted considerable foreign investment since the 2003 invasion, but even in spite of the IS insurgency to the country's north, Iraqi production broke production records in December of $2015,{ }^{47}$ continuing to increase output throughout the latter half of $2016 .^{48}$ In fact, recent training missions and air support provided by U.S. and coalition forces have proved increasingly successful in halting the advance of the Islamic State, and in many cases aided in the retaking of ground. ${ }^{49}$ As in many other cases, focusing on the professed rationales at play may do a disservice to the achievement of more pragmatic economic and strategic concerns.

\section{Africa}

The wide range of strategic concerns and assistance types observed in the Middle East have become increasingly prevalent throughout Africa in recent years. Reflecting the complex mixture of rationales driving engagement in other regions, and the growing interlinkage of threats with the Middle East, there appears to have been an expansion in security assistance programs to African states in the last decade. Whilst many have a distinct strategic element to them, in some

\footnotetext{
${ }^{45}$ Security Assistance Monitor, Military Aid Database, Center for International Policy. http://securityassistance.org/data

${ }^{46}$ Doug Stokes, "Blood for oil? Global capital, counter-insurgency and the dual logic of American energy security" Review of International Studies 33:2 (2007) pp, 245-264

${ }^{47}$ International Energy Agency, “ Oil Market Report Highlights - December 2015” December 11, 2015.

https://www.iea.org/media/omrreports/fullissues/2015-12-11.pdf; U.S. Energy Information Administration, “Country Analysis Brief: Iraq" January 30, 2015. http://www.eia.gov/beta/international/analysis includes/countries_long/Iraq/iraq.pdf

${ }^{48}$ International Energy Agency, "IEA releases Oil Market Report for October" October 11, 2016. https://www.iea.org/newsroom/news/2016/october/iea-releases-oil-market-report-for-october.html

49 "Dec.29: Iraqi Security Forces seize Ramadi Government Center" United States Central Command, December 29, 2015.

http://www.centcom.mil/en/news/articles/dec.-29-iraqi-security-forces-seize-ramadi-government-center
} 
cases these interests may be construed as more narrowly economic. For example, General Charles Wald, former Deputy Commander of United States European Command clearly linked US security assistance to economic reforms designed to open up African economies. He argued that US assistance was designed to help "partner nations on the continent of Africa build their capacity to better govern their spaces" so as to facilitate the "increased globalization of their economies, as well as the development of their societies for the betterment of their people."50 With that said, relatively speaking, direct military aid to African nations has been limited when compared with Latin America and the Middle East. Most of the aid disbursed by the State Department takes the form of the Global Health Program funds, with security programs such as INCLE and FMF accounting for negligible amounts. ${ }^{51}$ Nevertheless, the US engages in pervasive military training. Indeed, outside of missions in Iraq and Afghanistan, regularly the top three recipients of American training programs over the last few years have all been African nations, namely Burundi, Nigeria, and Uganda. ${ }^{52}$ A detailed breakdown reveals that the majority of this training is conducted under the Global Peace Operations Initiative (GPOI) and Peacekeeping Operations (PKO), programs that intend to build partner nation capacity in undertaking military operations, particularly peace support operations. ${ }^{53}$

While Burundi and Uganda, two underdeveloped and resource poor nations, receive military training solely in respect to building their capacity to engage in peace support operations, Nigerian military training has a number of economic linkages. Nigeria is Africa's most populous nation, largest economy and the largest recipient of US FDI primarily directed to its petroleum and mining sectors. This is unsurprising given that Nigeria is Africa's largest oil producer, and a growing market for many Western and East Asian nations keen to diversify supply away from

\footnotetext{
${ }^{50}$ Department of Defense, 'Special DOD briefing with Gen. Ward and Admiral Ulrich from the Pentagon, Arlington, VA', 15 Oct. 2007, http://www.defenselink.mil/transcripts/transcript.aspx?transcriptid=4059

${ }^{51}$ U.S. Department of State, "Congressional Budget Justification - Foreign Assistance. Summary Tables, FY2016" $\mathrm{p}, 7$

http://www.state.gov/documents/organization/238223.pdf

${ }^{52}$ Security Assistance Monitor, Military Aid Database, Center for International Policy. http://securityassistance.org/data

${ }^{53}$ See, for instance U.S. Department of State, "Joint Report to Congress - Foreign Military Training FY2013-14, Volume 1" http://www.state.gov/documents/organization/230192.pdf ; U.S. Department of State, "Joint Report to Congress - $\quad$ Foreign Military Training FY2011-12, Volume 1" http://www.state.gov/documents/organization/197595.pdf
} 
the Middle East. However, it is also a nation that has suffered for many years with a number of insurgent movements and criminal enterprises operating within its territory, contributing to significantly disrupt oil production. ${ }^{54}$ Due to recent events, Boko Haram, the Islamist group with connections to the Islamic State, has taken centre stage as the most prominent insurgent group in the country. However, Nigeria has long experienced insurgent activity in the Niger Delta, a response to the tensions over oil exploration in the region and local perceptions of exploitation. ${ }^{55}$ This, in turn, has also become mixed up with a surge in piracy that has been witnessed in the Gulf of Guinea, which itself intricately related to the broader disorder is emanating from the Delta itself. ${ }^{56}$ In 2013 it was reported that piracy in the Gulf Guinea surpassed that in the Gulf of Aden, a development that shows up in the detailed breakdown of U.S. training programs, with a proportion of fiscal year 2014 expenditure tailored toward maritime protection training. ${ }^{57}$

An interesting component of this relationship is that U.S. imports of Nigerian oil have collapsed over the last few years, falling from over $10 \%$ of U.S. imports to well under $1 \%$ as of late 2014 . $^{58}$ In fact, in July of 2014 it was reported that the United States didn't import a single barrel. ${ }^{59}$ The core driving force for this, unexpectedly, was the amount of domestically produced light, sweet crude coming online in the United States as a result of the shale revolution. Yet, to the extent that American demand has dropped European imports have increased to take up the slack, with European nations absorbing around $50 \%$ of Nigerian exports. ${ }^{60}$ In some senses this would suggest a lessened importance of Nigeria to the United States, yet this would belie the extent to which the United States has considered policing and securing global energy security a core

\footnotetext{
${ }^{54}$ U.S. Energy Information Administration, “Country Analysis Brief - Nigeria”, February 27, 2015. http://www.eia.gov/beta/international/analysis includes/countries long/Nigeria/nigeria.pdf

55 For a primer see, Stephanie Hanson, "MEND: The Niger Delta’s Umbrella Militant Group” Council on Foreign Relations, March 22, 2007. http://www.cfr.org/nigeria/mend-niger-deltas-umbrella-militant-group/p12920

${ }^{56}$ UN Office on Drugs and Crime, "Transnational Organized Crime in West Africa: A Threat Assessment", February 2013.

https://www.unodc.org/documents/data-and-analysis/tocta/West_Africa_TOCTA_2013_EN.pdf

57 U.S. Department of State, "Joint Report to Congress - Foreign Military Training FY2013-14, Volume 1" pp, 38-39http://www.state.gov/documents/organization/230192.pdf

${ }^{58}$ U.S. Energy Information Administration, "Country Analysis Brief - Nigeria”, February 27, 2015.

${ }^{59}$ Javier Blas, "Victim of shale revolution, Nigeria stops exporting to US" Financial Times, October 2, 2014. http://blogs.ft.com/beyond-brics/2014/10/02/victim-of-shale-revolution-nigeria-stops-exporting-oil-to-us/

${ }^{60}$ U.S. Energy Information Administration, “Country Analysis Brief - Nigeria”, February 27, 2015.
} 
interest throughout the post-War period. ${ }^{61}$ Indeed, with the growing salience of non-Middle Eastern oil producers combined with increasingly fraught domestic political environments for many of these nations, U.S. security assistance is, in fact, increasing. ${ }^{62}$ While many of these states face barriers to assistance in respect to their human rights records and history of corruption and incompetence, growing Islamist insurgencies in many African nations have refocused priorities.

The above illustrates the role that these pervasive and diffuse funding streams, training programmes and arms sales have played in stabilising forms of political-economic order that are deemed valuable to American policy planners. Linked back to issues over strategic policy, these examples also provide a potentially interesting insight into the manner in which such activity contributes to achieving broader strategic objectives. Not only, as has been illustrated in a number of these cases, do these operations contribute to secure an attractive, positive-sum order for a number of other important nation states, but they often also help achieve outcome that the application of traditional, large scale military force is incapable of attaining. In these sense, they also tend to prove more fungible with regard to the objectives of the specific operation or funding stream, not to mention working out as proportionally and relatively cost effective.

\section{A Strategic Continuum}

In light of this, our analysis suggests that there are substantial limitations to isolating interstate balance of power dynamics as the sole causal element driving international competition. It is often necessary to look beyond interstate balances of power and analyse the manner in which foreign intervention, whether physical or financial, may come to influence relative power dynamics and strategic balances. This becomes particularly pertinent when we consider the role these processes have played in attaining strategic goals, whether that be the limited aims of

\footnotetext{
${ }^{61}$ Doug Stokes and Sam Raphael, Global Energy Security and American Hegemony (Baltimore: The Johns Hopkins University Press, 2010)

${ }^{62}$ U.S. Department of State, "Congressional Budget Justification, Department of State, Foreign Operations, and Related Programs FY2016”February 2, 2015. P, 175 http://www.state.gov/documents/organization/236395.pdf ; U.S. Department of Defense, "Counterterrorism Partnerships Fund, Department of Defense Budget FY2016", March 2015. http://comptroller.defense.gov/Portals/45/Documents/defbudget/fy2016/FY2016_CTPF_J-Book.pdf
} 
'access' to which US funds were put in Pakistan, through to long term stabilization of the security environment in regards to Israel and Egypt. The willingness to commit funds and training, if not engage in actual military operations, have formed vital components of US power projection and statecraft throughout the twentieth and twenty-first centuries. In relation to ongoing debates in policy and scholarly communities regarding grand strategy, the absence of discussion on the topic is not unsurprising but the implications may be important. While there is considerable debate over the role that balance of power dynamics play in coming to fill the power gap left by proposed American retrenchment, there is an absence of discussion over what alterations (if any) would be made to intrastate stabilization operations and funds. Or, indeed, how they may factor into retrenched grand strategies more generally.

While deep engagement and retrenchment advocates argue over the relative merits and costs of different American force postures, they seldom discuss intrastate balances. In fact, intrastate interventions are often only used to illustrate the dangers of overextension; conflating rather controversial liberal democratic interventions with the broader, more frequent array of American interventions throughout the last century. As we have shown, this obscures a significant part of American international activity since at least 1900, where many deployments have been in support of smaller ambition, less intense intrastate interventions. While the deterrence and prevention of great power war is the obvious priority for American strategic planners and theorists, the exclusion of intrastate dynamics still retains significance. For instance, as we have shown, the United States has often used its security assistance streams to aid in attaining broader economic objectives. Whether this be stabilizing an allied regime or assisting through providing 'leverage' in attaining economic reforms, security assistance has on many occasions aided in creating and securing forms of political-economic order that benefit the United States, and that takes place alongside a broad strategic continuum based around both interstate and intrastate forms of conflict.

In figure 2, we provide a pictorial representation of such a continuum, labelling the strategic 'resolution' of key concepts in the literature. As we can see, traditional balancing dynamics are 
located firmly at the interstate end of the continuum, for the simple reason that they innately deal only with interstate power balances. The two concepts of 'micro-level structuring' and 'macro-level structuring', as offered by Brooks and Wohlforth, find themselves further down the scale, yet also stop short of dealing with specific intrastate dynamics.

\section{Figure 2. 'Strategic Resolution'}

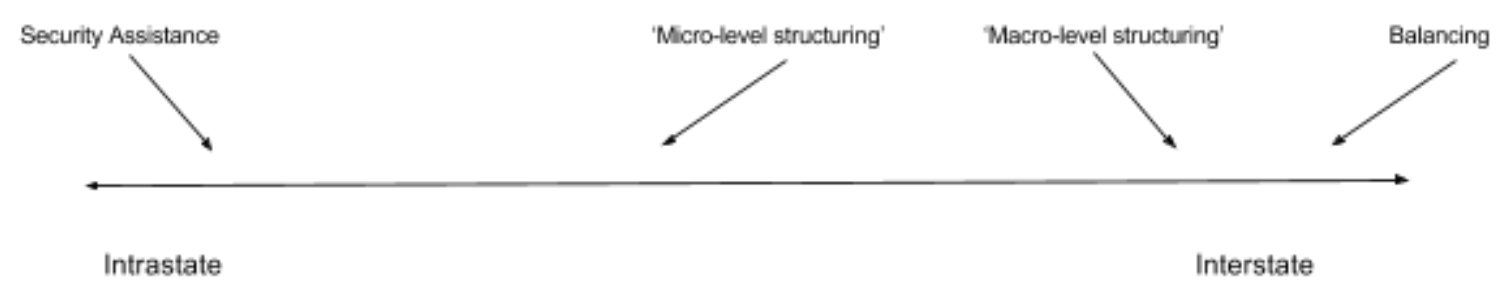

But what exactly do these concepts cover? And how does conceptualising security assistance as an integral component in grand strategic resolution correct for the disconnect between the extant literature on grand strategy and the empirical work we laid out above?

As we covered in the literature review, intrastate dynamics are often omitted in the grand strategy scholarship which instead focuses on global balance of power considerations. In this sense, the strategic resolution employed often starts and ends at the interstate. The limited engagement with this problem is well characterised by Layne's response to concerns over 'environment shaping', that is arguments concerning "the consequences of Eurasia's political and ideological, as well as economic, closure." Suggesting that "this threat is easily exaggerated, and manipulated, to disguise ulterior motives for U.S. military intervention." ${ }^{63}$ Layne bases this argument on the assumption that irrespective of American security assistance or military deployments, any given regional state still have a "stake in its own economic well-being....unlikely to hive itself off completely from international trade" ${ }^{\prime 4}$ itself a function of

\footnotetext{
${ }^{63}$ Layne, The Peace of Illusions, 177

${ }^{64}$ Layne, The Peace of Illusions, 178
} 
the fact that "because its export markets, and sources of imports, are diversified no single overseas region is crucial to America's economic well-being." ${ }^{\prime 65}$

Yet, as ever, the devil is in the details. The United States, as we have demonstrated, prefers certain forms of political economy over others - actively linking security assistance and arms sales to achievement of economic outcomes. America's military support of Saudi Arabia would be far from certain without some interest in their oil, for instance. Moreover, security assistance does not often entail any significant commitments, with the selling of arms to a nation or the training of its military not necessitating any formal commitments to defence in times of conflict. The broader point to make, however, is given that intrastate dynamics have been so central to American foreign policy over the last century, even offshore balancing strategies should articulate some detail of response to this problem. Even if that is, à la Layne, and more formal expression of disinterest based on a relative 'cost - benefit' analysis. That is, that the perception that the 'returns' on these operations do not exceed the efforts and risk involved in undertaking them.

A more complete analysis would therefore go a step further than this, adding in dynamics that operate at the intrastate level as well. For instance, theorising as to whether and how to mitigate the "significant security consequences associated with weak or failing states" finds little place in the aforementioned work, yet is mentioned in-depth in the United States National Security Strategy (NSS) of 2015. ${ }^{66}$ It remains to be seen how the Trump Administration will approach these issues, but there is no reason to assume that intrastate conflicts will diminish in their intensity or prevalence. Equally, the problems associated with failed states are only a small part of the intrastate dynamics we cover above, demonstrating limitations in the existing official strategic documentation too. However, as our analysis hopes to demonstrate, great power

\footnotetext{
${ }^{65}$ Layne, The Peace of Illusions, 177

${ }^{66}$ The White House, "National Security Strategy" February 2015. https://www.whitehouse.gov/sites/default/files/docs/2015 national_security_strategy.pdf
} 
competition occurs at all levels of analysis simultaneously, limiting the resolution at which certain strategic doctrines and concepts are operational. ${ }^{67}$

\section{Conclusion}

At the moment, a large swath of the literature on US grand strategy focuses largely on interstate balances of power, omitting the intrastate dynamics that have proved vital in achieving broader strategic goals. This is justifiable given how transformational major interstate wars are for US national security interests. However, whilst on a lower order of threat, intrastate conflict and instability has played a major role in US coercive statecraft. Going forward, whether it is fighting Islamist terrorism in the Middle East, intervening in ongoing and bloody civil wars or engaging in intrastate proxy wars with great power rivals, they look likely to continue to be part of America's strategic calculus. Moreover, funding and involvement in intrastate conflict and competition has formed a vital component of the way in which the United States has promoted specific forms of regional political economy and maintained its global leadership. In short, the intrastate dimension matters. Our paper has attempted to address this element and relate it to grand strategic debates and called for a broader strategic continuum that, minimally, addresses these crucial intrastate conflict dynamics.

Just as importantly, we have attempted to demonstrate how this problem influences both major schools of grand strategic thought, broadly categorised as offshore balancing and deep engagement. As we have attempted to illustrate, and as the historiography of the Cold War aptly demonstrates, international competition takes place at all levels of analysis. Given this, an articulation of how, and at what level, a specific grand strategic logic operates is of importance to academic and policy oriented debates alike. For example, while key proponents of both strategies are adverse to 'liberal hegemonic' interventions this aversion explains very little about their attitudes to other forms of intrastate activity, despite the empirical prevalence and importance of

\footnotetext{
${ }^{67}$ The core logic of a specific grand strategy can be married with a number (if not mixture) of different peripheral strategic logics, all of which may have corresponding implications for force posture and procurement patterns. See for example Derek Reveron, Exporting Security: International Engagement, Security Cooperation, and the Changing Face of the U.S. Military (Washington: Georgetown University Press, 2010)
} 
these forms of competition and conflict. A problem we believe can be addressed by a broader strategic continuum that extends analysis beyond interstate distributions of power. 